\title{
BAHASA SEBAGAI SALAH SATU SISTEM KOGNITIF ANAK USIA DINI
}

\author{
Naili Sa'ida \\ FKIP Universitas Muhammadiyah Surabaya \\ nelysaida@gmail.com
}

\begin{abstract}
ABSTRAK
Bahasa adalah alat untuk berpikir, mengekspresikan diri dan berkomunikasi. Bahasa mencakup setiap sarana komunikasi dengan menyimbolkan pikiran dan perasaan untuk menyampaikan makna kepada orang lain. Perkembangan kognitif dan perkembangan bahasa anak memiliki hubungan yang erat. Bahasa mempunyai peranan yang sangat penting terhadap proses berpikir anak. Dengan bahasa anak dapat lebih mudah memahami suatu informasi maupun kemampuan yang baru. Kemampuan berbahasa seseorang banyak dipengaruhi oleh kapasitas kemampuan kognitifnya. Besarnya kesempatan yang diperoleh untuk melakukan proses belajar dari lingkungannya mempengaruhi kemampuan berbahasa anak.
\end{abstract}

Kata Kunci: bahasa, kognitif, anak usia dini.

\begin{abstract}
Language is a tool for thinking, expressing and communicating. Language includes every means of communication by symbolizing thoughts and feelings to convey meaning to others. The cognitive development and language development of children has a close relationship. Language has a very important role to the thinking process of children. With the language of the child can more easily understand a new information and capabilities. The ability to speak a person is influenced by the capacity of his cognitive ability. The amount of opportunity gained for the learning process of the environment affects the child's language skills.
\end{abstract}

Keywords: language, cognitive, early childhood

\section{PENDAHULUAN}

Pandangan masyarakat pada bahasa anak usia dini selama ini banyak yang mengacu pada teori nativisme, terutama untuk kalangan menengah ke bawah. Mereka menganggap bahwa anak dapat menggunakan bahasa sesuai dengan fungsinya tanpa harus mendapatkan stimulus yang baik. Masyarakat awam hanya mengandalkan bahwa anak mempunyai potensi kecerdasan masing-masing. Cakap dan tidaknya anak menggunakan bahasa sesuai fungsinya tergantung dari potensi yang mereka bawa sejak lahir. Mereka tidak menyadari bahwa pada usia dini, anak mengalami lonjakan yang besar pada perkembangan kognisinya.

Berbeda dengan masyarakat menengah ke atas mereka mempunyai pandangan selain kemampuan berbahasa dipengaruhi oleh kemampuan kognitif, mereka juga memiliki pemahaman bahwa 
kemampuan bahasa anak didapat dari stimulus-stimulus yang berasal dari luar diri anak (lingkungan). Seorang anak yang mendapatkan stimulus dalam berbahasa yang tidak sesuai dengan karakteristik tahap perkembangan mereka, maka stimulus tersebut dapat membuat mereka kehilangan masa bermain yang berakibat timbulnya rasa kejenuhan pada proses belajar.

Melihat dua gambaran masalah yang terjadi saat ini selayaknya lingkungan yaitu orang tua, guru dan masyarakat harus memahami bahwa setiap anak perkembangan bahasanya sangat berkaitan erat dengan potensi dan karakteristik perkembangan kognitif anak pada usia dini. Tingkat kognitif anak dapat terlihat dari perilaku berbahasa anak. Semakin cakap anak dalam berbahasa maka semakin tinggi pula tingkat kognitif anak.

\section{Perkembangan Bahasa Anak Usia Dini}

Bahasa adalah alat untuk berpikir, mengekspresikan diri dan berkomunikasi. Salah satu bidang pengembangan pertumbuhan kemampuan dasar di taman kanakkanak adalah pengembangan bahasa. Bahasa memungkinkan anak untuk menerjemahkan pengalaman ke dalam simbol-simbol yang dapat digunakan untuk berkomunikasi dan berpikir. Bahasa erat kaitannya dengan perkembangan kognitif.

$$
\text { Silberman }
$$

(2007:3),

mengemukakan bahwa perkembangan bahasa adalah proses perkembangan bahasa dari bahasa yang tidak jelas, berubah menjadi bahasa yang jelas, langsung dan terkontrol.

Perilaku berbahasa akan membantu anak-anak membuat konsep dalam dunia mereka, merubah dari egosentris menjadi berkomunikasi dan bersosial dengan orang lain, membimbing dan mengontrol anak, menumbuhkan pemikiran, perasaan dan merasa aman dan tidak aman melalui bahasa yang anak dengar dan gunakan.

Menurut

Nurbiana

Dhieni,dkk

(2007:1.11)

mengemukakan bahwa dalam perkembangan bahasa anak usia dini terdapat 4 (empat) keterampilan berbahasa yaitu: keterampilan menyimak, keterampilan berbicara, keterampilan membaca, dam keterampilan menulis.

\section{Perkembangan Kognitif AUD}

Kemampuan kognitif berkaitan dengan semua proses psikologis yang berkaitan dengan bagaimana individu mempelajari dan memikirkan lingkungannya. Menurut Berk dalam Vina Adriany (2014) mengemukakan bahwa perkembangan kognitif adalah kapasitas intelektual yang dimiliki oleh seorang anak dan bagaimana kapasitas tersebut berkembang sampai mereka dewasa kelak.

Perkembangan kognitif meliputi perubahan pada aktivitas mental yang berhubungan dengan persepsi, pemikiran, ingatan, keterampilan berbahasa dan 


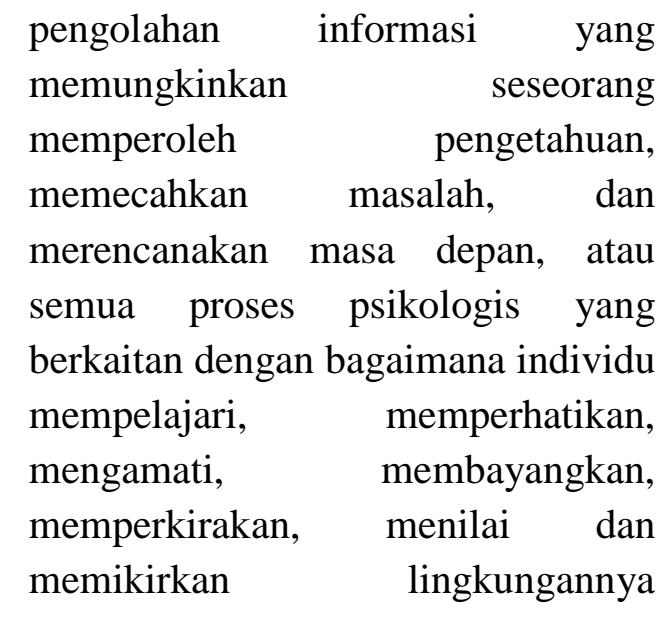

(Desmita, 2009:258).

Pendekatan-pendekatan

perkembangan kognitif menekankan pada cara anak secara aktif membangun pemikirannya. Pendekatan tersebut juga sangat berfokus pada cara berpikir anak yang berubah dari satu titik perkembangan ke titik perkembangan berikutnya. Proses yang digunakan anak ketika membangun pengetahuan mereka mencakup skema, asimilasi dan akomodasi (Santrock, 2012:7).

Menurut Berk dalam Vina Adriany (2014) mengemukakan bahwa terdapat tiga faktor yang dapat mempengaruhi perkembangan kognitif anak yaitu faktor hereditas, faktor kematangan individu dan faktor belajar.

\section{Karakteristik Perkembangan Bahasa dan Kognitif AUD Karakteristik Bahasa AUD}

Bahasa mencakup setiap sarana komunikasi dengan menyimbolkan pikiran dan perasaan untuk menyampaikan makna kepada orang lain. Termasuk didalamnya tulisan, bicara, bahasa simbol, ekspresi muka, isyarat, pantomim dan seni. Tidak semua bunyi/suara yang dikeluarkan anak dapat disebut berbicara. Hurlock dalam Soetjiningsih (2012:169) mengemukakan bahwa berbicara merupakan sarana berkomunikasi. Sampai bayi berusia 18 bulan, komunikasi dalam bentuk kata-kata harus diperkuat dengan isyarat, seperti menunjuk benda. Pada usia dua tahu, rata-rata bayi sudah dapat mengerti beberapa perintah sederhana. Bagi bayi, belajar bicara merupakan tugas yang tidak mudah. Bentuk komunikasi pada masa ini disebut bentuk-bentuk prabicara yang biasanya terdapat empat bentuk prabicara, yaitu menangis, berceloteh, isyarat dan pengungkapan emosi.

Fungsi bahasa yang utama adalah sebagai alat untuk berkomunikasi. Bahasa sebagai sarana untuk berpikir dan bernalar. Manusia menggunakan bahasa untuk berpikir, menyimak, berbicara, membaca dan menulis. Namun, kemampuan menggunakan bahasa itu tidaklah merupakan kemampuan yang bersifat alamiah seperti bernafas dan berjalan. Kemampuan itu tidak dibawa sejak lahir dan dikuasai dengan sendirinya, melainkan harus dipelajari.

Menurut McCormick, Loeb \& Schiefelbusch dalam Mary Renck Jalongo (2007:62) rentang waktu perkembangan bahasa anak/ balita ada beberapa tahap, diantaranya:

a. Komunikasibentuk pertama adalah menangis. Ada beberapa 
perbedaan dari tangisan. Sebuah tangisan yang begitu keras sering menandakan tidak hanya dari intensitas tangisannya melainkan berapa jumlah jeda atau berapa banyak anak bernafas disela-sela tangisannya.

b. Ketika anak bertambah usianya, mereka membuat suara dan gerakan. Pada awalnya, anak membuat suara vokal pada satu bulan mereka (misalnya, ooohh, "" ahhh"). Pada usia 4 atau5 bulan, mereka mulai menggunakan bagian belakang tenggorokan mereka untuk membuat suara konsonan. Pada sekitar usia 12 bulan, mereka terhubung ucapan vokal dan konsonan secara bersama-sama, jenis ucapan ini disebut lallation (misalnya, "mamama"). Urutan suku kata konsonan/vokal ini mencapai sekitar setengah dari suara tangisan bayi dari usia 6 sampai 12 bulan.

c. Kemampuan Balita untuk memahami bahasa jauh lebih maju dari pada kemampuan mereka untuk menghasilkan bahasa (yang ekspresif). Antara 8 bulan dan $1 \frac{1}{2}$ tahun, bayi menggunakan istilah yang ekspresif, dengan intonasi bahasa. Pada waktu yang sama, bayi mulai menggunakan kata-kata tunggal (holophrases) yang dapat dimengerti dengan yang lain.

d. Balita dan anak usia 3 tahun cenderung memahami ucapan, kata yang dihubungkan bersama tanpa ada akhir kata kerja (misalnya, -ed, -ing), kata penghubung (misalnya, dan), kata keterangan (misalnya, pada, di), dan kata ganti (misalnya, aku, dia). Meskipun bahasa anak bervariasi, balita mudah menerima (mendengarkan) kosakata (Griffiths, 1986). Pada usia duatahun anak hanya belajar bagaimana berkomunikasi dan biasanya tidak memperpanjang percakapan berulang-ulang dan jangan mempertahankan topik yang sudah lama.

Bayi-bayi secara efektif mengeluarkan suara sejak ia dilahirkan. Tujuan berkomunikasi awal ini adalah menarik perhatian pengasuh-pengasuhnya dan orangorang lain dalam lingkungannya.

Menurut Diane E. Papalia, Sally Wendkos Old \& Ruth Duskin Feldman (2010:235), karakteristik perkembangan bahasa anak sebagai berikut:

a. Lahir, dapat mengenali percakapan, menangis, membuat semacam respon terhadap suara.

b. Rentang usial $1 / 2$ sampai 3 bulan, mengeluarkan suara "uuu" dan tertawa. Pada usia 3 bulan, bermain dengan suara biacara (speech sound).

c. Rentang usia 5 sampai 6 bulan, membuat suara konsonan, mencoba untuk menyesuaikan dengan apa yang ia dengar.

d. Rentang usia 6 sampai 10 bulan, mengoceh huruf konsonan dan vokal. Pada usia 9 bulan, menggunakan gerakan tubuh untuk berkomunikasi dan bermain 
gerakan tubuh, sedangkan pada usia 9 sampai 10 bulan, mulai memahami kata (biasanya adalah kata "jangan" dan namanya sendiri) meniru suara.

e. Rentang usia 10 sampai 12 bulan, tidak lagi dapat membedakan suara yang bukan berasal dari bahasa ibu. Pada usia 9 sampai 12, menggunakan sedikit gerak tubuh sosial.

f. Rentang usia 10 sampai 14 bulan, mengucapkan kata pertama (biasanya nama sesuatu).

g. Rentang usia 10 sampai 18 mengucapkan kata tunggal. Pada usia 13 bulan, mulai memahami fungsi simbolis penamaan, menggunakan gerakan tubuh yang lebih rumit, sedangkan pada usia 14 bulan, menggunakan gerak tubuh simbolik

h. Rentang usia 16 sampai 24 bulan, belajar banyak kata baru, mengembangkan kosakata dengan cepat dari mulai 50 kata menjadi 400 kata, menggunakan kata kerja sifat. Pada usia 18 sampai 24 bulan, mengucap kalimat pertama (dua kata). Pada usia 20 bulan semakin sedikit menggunakan gerak tubuh, lebih banyak menamai benda. Pada usia 20 sampai 22 bulan memiliki ungkapan yang komprehensif, sedangkan pada usia 24 bulan menggunakan banyak frasa dua kata, tidak lagi mengoceh, ingin berbicara.

i. Rentang usia 30 bulan, belajar kata baru hampir setiap hari, berbicara dengan kombinasi dua atau tiga kata dengan baik.

j. Rentang usia 36 bulan, mengucapkan 1000 kata, 80 persen dapat dimengerti, membuat beberapa kesalahan dalam sintaksis.

\section{Karakteristik Kognitif AUD}

Membangun pengetahuan dalam perkembangan kognitif merupakan salah satu dari aspek perkembangan anak usia dini. Kemampuan kognitif anak usia dini berkembang secara bertahap, sejalan dengan perkembangan fisik dan syaraf-syaraf yang berada di pusat susunan syaraf. Piaget (1896-1980) dalam Soetjiningsih (2012: 168) mengemukakan karakteristik perkembangan kognitif berdasarkan tahapannya:

a. Sensori-motorik (0-2 tahun)

Intelegensi nampak dalam bentuk aktivitas motorik sebagai respon. Awalnya refleks, kemudian ada diferensiasi yang jelas antara subjek dan objek. Terjadinya permanensi objek dan ada proses desentrasi.

b. Pra-operasional (2-7 tahun)

Penguasaan bahasa yang sistematis, permainan simbolis, imitasi (tidak langsung), bayangan dalam mental, berpikir egosentris, centralized (memusat), irreversible (tidak dapat dibalik), terarah statis.

c. Operasional konkret (7-11 tahun)

d. Operasional formal (11 tahun keatas)

Perkembangan kognitif dan perkembangan bahasa anak memiliki 
hubungan yang erat. Hal ini terbukti bahwa pada usia 36 bulan atau 3 tahun anak dapat menguasai kurang lebih 1000 kata, sejalan dengan perkembangan fungsi kognitif pada otak anak yang berusia 3 tahun lebih dari $50 \%$ fungsi otak mengalami perkembangan dengan pesat.

Diperkuat dengan hasil penelitian yang dilakukan oleh Vygotsky bahwa bahasa mempunyai peranan yang sangat penting terhadap proses berpikir anak. Dengan bahasa anak dapat lebih mudah memahami suatu informasi maupun kemampuan yang baru, penggunaan private speech saat anak melakukan suatu kemampuan yang baru maka akan terjadi inner speech yaitu pemikiran-pemikiran pribadi anak (Santrock, 2007:265). Hal tersebut membuktikan bahwa peranan bahasa dan perkembangan kognitif anak mempunyai peran yang besar. Anak-anak yang melakukan private speech lebih penuh perhatian dan dapat menunjukkan kinerja yang lebih baik dari pada anak yang tidak melakukan private speech.

Sebuah eksperimen yang menunjukan begitu eratnya bahasa dalam perkembangan hidup bagi individu. Pada abad ke- 13 kaisar Jerman Frederick II memilih beberapa bayi mengancam pengasuh dengan hukuman mati jika mereka mengajak bicara bayi-bayi itu, dan ternyata pada bayi-bayi itu tidak ditemukan bahasa karena semua mati (Santrock, 2007:374). Hal tersebut menunjukkan kaitan erat penggunaan DAFTAR PUSTAKA bahasa dengan perkembangan otak individu atau anak. Dikisahkan pada banyak kasus yang telah terjadi dan hal ini menunjukkan eratnya pengaruh bahasa terhadap kognisi anak.

Kemampuan berbahasa seseorang banyak dipengaruhi oleh kapasitas kemampuan kognitifnya. Selain itu, besarnya kesempatan yang diperoleh untuk melakukan proses belajar dari lingkungannya. Individu yang banyak berinteraksi dengan lingkungan yang kaya kemampuan berbahasanya, akan memiliki kesempatan yang lebih banyak dan bagus dalam mengembangkan kemampuan bahasanya, sedangkan individu yang banyak berinteraksi dengan lingkungan yang miskin atau kurang kemampuan berbahasanya, akan cenderung terbatas pula kesempatan untuk mengembangkan kemampuan bahasanya.

\section{KESIMPULAN}

Berdasarkan tinjauan pustaka di atas, terlihat jelas bahwa keterkaitan antara kemampuan kognitif dengan kemampuan bahasa seorang individu dan begitupun sebaliknya. Anak yang memiliki kemampuan bahasa yang bagus maka kemampuan kognitif anak juga akan berkembang dengan baik. Begitu pula dengan anak yang memiliki kemampuan bahasa yang rendah akan juga akan mempengaruhi perkembangan kognitif anak. 
Christina Hari Soetjiningsih. 2012. Perkembangan Anak Sejak Pembuahan Sampai dengan Kanak-kanak Akhir. Jakarta: Prenada Media Grup.

Desmita. (2009). Psikologi Perkembangan Peserta Didik. Bandung: Remaja Rosdakarya.

John W. Santrock. (2012). Life-Span Development, Perkembangan Masa Hidup Edisi Ketigabelas. Jakarta: Erlangga PT. Gelora Aksara Pratama.

Mary Renck Jalongo. (2007). Early Childhood Language Arts. United States of Amerika: Pearson Education.

Nurbiana Dhieni, dkk, (2007). Metode Pengembangan Bahasa. Jakarta: Universitas Terbuka.

Silberman, Mel. (2007). Active learning-101 Strategies to teach any subject. USA Massachusetts: A Silmon \& Schuster Company. Sonawat,
Diane E. Papalia, Sally Wendkos Old \& Ruth Duskin Feldman. (2010). Human Development. Jakarta: Kencana.

Jhon W. Santrock. (2007). Perkembangan Anak Jilid I. Jakarta: Erlangga.

Reeta dan Jasmine Maria. Language Development For Preschool Children. Mumbai: Multitech Publishing Co.

Suhartono. (2005). Pengembangan Keterampilan Bicara Anak Usia Dini, Jakarta:Departemen Penddikan Nasional.

Vina Adriany. (2014). Optimalisasi perkembangan anak usia dini melalui kegiatan penyuluhan deteksi dini tumbuh kembang anak, diakses dari http://jurnal.upi.edu/file/Vina. pdf, pada tanggal 19 september 2014 pukul 5.59 WIB. 